\title{
PENGARUH KEMAMPUAN MEMBACA PETA TERHADAP PENGUASAAN KONSEP INTERAKSI KERUANGAN PADA SISWA SMA NEGERI DI KOTA MEDAN
}

Oleh:

\author{
Nurmala Berutu, Asnidar, dan Ali Nurman*
}

\begin{abstract}
Abstrak
Tujuan penelitian ini adalah untuk mengetahui: kemampuan membaca peta, penguasaan konsep interaksi keruangan, dan besar hubungan antara kemampuan membaca peta dengan penguasaan konsep interaksi keruangan pada siswa SMA Negeri kota Medan. Penelitian ini adalah penelitian korelasional. Pengumpulan data dilaksanakan pada bulan Mei 2012. Jumlah responden sebanyak 243 orang siswa yang diambil secara acak sederhana Data dikumpulkan dengan menggunakan tes kemampuan membaca peta dan penguasaan konsep interaksi keruangan kemudian dianalisis dengan menggunakan statistik deskriptif, regresi dan korelasi sederhana. Hasil penelitian menunjukkan bahwa kemampuan membaca peta pada siswa SMA Negeri kota Medan masing rendah $(39,51 \%)$ dan demikian juga dengan penguasaan konsep interaksi keruangan $(55,97 \%)$ dan terdapat hubungan positif dan berarti antara kemampuan membaca peta dengan penguasaan konsep interaksi keruangan sebesar $\quad(r=0,402)$ dengan persamaan regresi linear $\hat{Y}=3,04+0,28$ X. koefisien determinasi (r2) diperoleh sebesar 0,1616, artinya bahwa sebesar $16,16 \%$ variasi penguasaan konsep interaksi keruangan dapat dijelaskan oleh kemampuan membaca peta.

Kata Kunci : Kemampuan Membaca Peta, Konsep Interaksi Keruangan
\end{abstract}

\section{A. Pendahuluan}

Geografi menurut seminar dan lokakarya di Semarang tahun 1989, didefenisikan sebagai ilmu yang mempelajari persamaan dan perbedaan fenomena geosfer dengan sudut pandang kewilayahan dalam konteks keruangan (Sumaatmadja.2001). Berdasarkan defenisi tersebut pembelajaran geografi menitikberatkan pada permukaan bumi (geosfer), alam lingkungan (atmosfer, lithosfer, hidrosfer, dan biosfer), umat manusia dengan kehidupannya (antroposfer), penyebaran keruangan gejala alam dan kehidupan, termasuk persamaan dan perbedaan, serta analisis hubungan keruangan gejala-gejala geografi di permukaan bumi. Oleh karena itu lingkup pengajaran geografi meliputi: (1) alam lingkungan yang menjadi sumberdaya bagi kehidupan, (2) penyebaran manusia dengan variasi kehidupannya, (3) interaksi keruangan manusia dengan alam lingkungan yang memberikan variasi terhadap ciri khas tempat-tempat di permukaan bumi, (4) kesatuan 
regional yang merupakan perpaduan matra darat, perairan, dan udara di atasnya. Ruang lingkup inilah yang memberikan ciri dan karakteristik pembelajaran geografi di sekolah. Oleh sebab itu, apapun yang akan dibahas pada pembelajaran geografi, materinya selalu digali dari permukaan bumi pada suatu lokasi, untuk mengungkap corak kehidupan manusia yang memberikan ciri khas kepada wilayah yang bersangkutan sebagai hasil interaksi faktorfaktor geografis yang ada di dalamnya.

Faktor lokasi dalam pembahasan geografi merupakan konsep utama yang harus dipelajari arti dan pemakaiannya sejak tingkat SD sampai perguruan tinggi dengan kompleksitas dan kekhususan makna yang berbeda sesuai dengan jenjang pendidikan (sekolah). Pemahaman tentang lokasi secara baik terasa agak sulit, terutama apabila lokasi tersebut belum pernah diketahui atau dikenali. Oleh sebab itu dalam pembelajaran geografi di sekolah mutlak diperlukan adanya peta sebagai media pembelajaran.

Pada hakekatnya, peta merupakan gambaran utuh mengenai fenomena dalam suatu wilayah atau lokasi tertentu, dalam waktu tertentu, dan sekaligus akan dapat memberikan pemahaman mengenai distribusi, interaksi, dan asosiasi yang terjadi. Pola-pola interaksi dan distribusi yang terdapat dalam peta pada hakekatnya merefleksikan tentang perkiraan proses terjadinya dan keterkaitannya dengan aneka faktor yang melatarbelakangi. Kesemuanya merupakan fakta yang bisa ditampilkan dalam peta yang perlu dipahami oleh semua pihak yang menekuni bidang kajian geografi.

Sebagai salah satu media utama pembelajaran geografi, peta dapat digunakan untuk menyampaikan ide kepada orang lain, ide yang dimaksud dapat berupa tinggi rendahnya suatu daerah, penyebaran penduduk, penyebaran jenis tanah dan semua hal yang berhubungan dengan kedudukannya dalam ruang. Dengan menyajikan ke dalam bentuk peta diharapkan si penerima ide dapat dengan cepat dan mudah memahami atau memperoleh gambaran dari apa yang disajikan melalui indera penglihatannya (Sandy.1976). Penjelasan-penjelasan guru yang dibantu dengan peragaan peta akan mampu memberikan gambaran yang lebih jelas dalam pengertian kognisi, sehingga mempermudah penguasaan konsep interaksi keruangan.

Menurut Nurcahyanto (1988) Interaksi wilayah/keruangan adalah hubungan timbal balik yang saling mempengaruhi antara dua wilayah atau lebih yang dapat melahirkan gejala, kenampakan, dan permasalahan baru secara langsung maupun tidak langsung. Lebih lanjut Suharyono \& Amin (1994) menjelaskan interaksi 
wilayah/keruangan sebagai peristiwa saling mempengaruhi dayadaya, objek atau tempat satu dengan yang lain. Setiap tempat mengembangkan potensi sumber dan kebutuhan yang tidak selalu sama dengan apa yang ada di tempat yang lain. Oleh karena itu senantiasa terjadi interaksi wilayah/keruangan antara wilayah/ruang yang satu dengan lainnya.

Wilayah (ruang) merupakan bagian dari permukaan bumi yang dapat dibedakan dalam hal-hal tertentu dari daerah di sekitarnya (Bintarto.1979). Sumaatmadja (1988) menjelaskan bahwa wilayah/ruang adalah ruang di permukaan bumi yang memiliki individualitas tertentu. Di dalam wilayah/ruang terjadi interaksi keruangan yang memberikan ciri tertentu kepada ruang atau wilayah tersebut. Lebih lanjut disebutkan bahwa wilayah/ ruang merupakan wilayah geografi yang ukurannya bervariasi dari yang sangat luas sampai dengan yang sangat terbatas. Karakter terpenting yang harus dimiliki wilayah/ruang adalah homogenitas tertentu yang khas. Karakteristik yang khas itu dapat berupa aspek fisik ataupun aspek kultural.

Adisasmita (2008) menjelaskan bahwa wilayah/ruang merupakan sub-sistem spasial dari sistem wilayah secara nasional. Wilayah/ruang dapat dibedakan dalam tiga macam, yaitu (1) wilayah homogen (hogenius region), (2) wilayah polarisasi (polarization region) atau wilayah nodal (nodal region), (3) wilayah perencanaan (planing region) atau wilayah program (programing region). Lebih lanjut Sjafrizal (2008) menyatakan bahwa wilayah homogen merupakan kesatuan wilayah/ruang yang dibentuk berdasarkan kesamaan karakteristik dalam wilayah yang bersangkutan. Wilayah nodal merupakan kesatuan wilayah/ruang yang dibentuk berdasarkan keterkaitan yang erat antar daerah, sedangan wilayah perencanaan merupakan kesatuan wilayah/ruang yang dibentuk untuk tujuan penyusunan perencanaan pembangunan.

Pembahasan tentang ketiga bentuk wilayah yang telah dikemukakan, sesuai dengan peran yang berbeda dari setiap wilayah/ruang yang disebabkan oleh perbedaan unsur-unsur geografi. Hal ini sejalan dengan pendapat Temple (dalam Sjafrizal, 2008) bahwa terbentuknya klasifikasi wilayah/ruang disebabkan oleh perbedaan peranan antar wilayah. Menurut Wheeler, Kastbade dan Thomas dalam Suharyono dan Amien (1994) bahwa unsur-unsur geografi yang perlu dipahami dalam kajian wilayah/ruang meliputi: (1) lokasi, mencakup lokasi absolut dan relatif, (2) penduduk yang menyangkut jumlah, kepadatan, persebaran dan kecenderungannya, (3) status politik dan sejarahnya meliputi struktur pembagian administrasi 
pemerintahan, status kemandirian dan aspek sejarahnya, (4) lingkungan alam mencakup bentuk lahan, iklim, vegetasi, fauna, perairan dalam dan perairan permukaan, sumber kekayaan mineral, (5) tipe ekonomi yang meliputi mekanisme yang dikembangkan untuk memenuhi kebutuhan masyarakat, susunan mata pencaharian, (6) potensi-potensi apa yang mungkin dapat diangkat di masa depan yang menyangkut aspek keadaan alam dan keadaan penduduk dan kehidupannya, serta (7) permasalahan utama, baik yang bersumber dari keadaan penduduk seperti pertambahan penduduk yang cepat, persebarannya, perimbangan penduduk dengan sumber daya lahan, keanekaragaman ras, sistem pemilikan lahan dan pergolakan politik atau sosial yang mungkin timbul.

Ketujuh unsur-unsur geografi di permukaan bumi akan saling berinteraksi, dan akan membentuk karakter wilayah/ruang. Perbedaan karakter wilayah/ruang menyebabkan munculnya interaksi wilayah. Interaksi wilayah/ruang merupakan hubungan yang terjadi secara timbal balik dan saling mempengaruhi antara dua atau lebih wilayah/ruang dan menyebabkan timbulnya berbagai gejala, kenampakan atau permasalah baru pada wilayah/ruang yang berinteraksi.

Mengacu pada hasil semlok geografi di Semarang tahun 1989 tersebut salah satu konsep dalam pengajaran geografi adalah konsep interaksi keruangan. Suharyono \& Amin (1994) menjelaskan bahwa interaksi keruangan dapat dikaji melalui 4 aspek, yaitu :(1) adanya daya saling mempengaruhi antar wilayah, (2) perbedaan pengembangan potensi, sumber, dan kebutuhan antar wilayah, (3) perpindahan informasi, jasa, dan penduduk antar wilayah, dan (4) kaitan fenomena/unsur dalam suatu wilayah.

Hasil analisis kompetensi geografi SMA yang dilakukan peneliti menunjukkan bahwa konsep dasar interaksi keruangan banyak tertuang pada standar kompetensi 1 (satu), semester ganjil kelas XI, yaitu menganalisis fenomena biosfer dan antroposfer dengan kompetensi dasar: (1) Menjelaskan pengertian fenomena biosfer, (2) Menganalisis sebaran hewan dan tumbuhan dan (3) Menjelaskan pengertian fenomena antroposfer, dan Menganalisis aspek kependudukan. Berdasarkan kajian tersebut, maka penelitian ini akan dilaksanakan pada siswa SMA kelas XI semester genap, dengan dasar bahwa kompetensi ini telah mereka pelajari.

Dari pengalaman bertahun-tahun mengajar di Jurusan Pendidikan Geografi, kenyataan menunjukkan bahwa mahasiswa baru pada umumnya tidak memiliki pengetahuan yang baik tentang konsep geografi, diantaranya konsep interaksi keruangan yang tergambar pada peta, padahal semestinya konsep tersebut 
telah dimiliki pada tingkat SMA. Hal ini ditunjukkan juga oleh hasil tes kemampuan dasar (tes ELAQA) bagi mahasiswa baru Jurusan Pendidikan Geografi yang dilakukan lima tahun terakhir hanya dengan capaian skor maksimal 56. Penelitian ini juga didasari dari hasil penelitian terdahulu yang telah peneliti lakukan pada siswa SMP di Kota Medan, yang menunjukkan adanya hubungan positif dan berarti antara kemampuan membaca peta dengan penguasaan konsep region Indonesia dengan koefisien korelasi sebesar $r=0,491$ (Berutu dan Sidauruk, 2002). Hasil ini menunjukkan bahwa kemampuan membaca peta berperan dalam membentuk penguasaan konsep geografi pada siswa, termasuk konsep interaksi keruangan.

Bertitik tolak dari dasar pemikiran tersebut, maka penelitian ini bertujuan untuk mengetahui: (1) kemampuan membaca peta siswa SMA Negeri di Kota Medan, (2) penguasaan konsep interaksi keruangan siswa SMA Negeri di Kota Medan, dan (3) pengaruh kemampuan membaca peta terhadap penguasaan konsep interaksi keruangan siswa SMA Negeri di Kota Medan.

Hasil penelitian ini diharapkan menjadi salah satu referensi yang mampu meningkatkan motivasi guru geografi di SMA untuk mengintensifkan penggunaan peta pada proses pembelajaran geografi, sehingga tujuan peningkatan kualitas pembelajaran geografi bisa dicapai. Oleh karena itu diharapkan kepala sekolah dan dinas pendidikan memfasilitasi pengadaan peta guna kebutuhan pembelajaran geografi. Bagi Unimed sebagai Lembaga Pendidikan Tenaga Kependidikan (LPTK) khususnya Jurusan Pendidikan Geografi, hasil penelitian ini diharapkan menjadi masukan untuk terus memperbaiki kualitas lulusan terutama materi penguasaan konsep pemetaan.

\section{B. Metode Penelitian}

Penelitian ini dilakukan di SMA Negeri Kota Medan yang pengumpulan data dilaksanakan bulan Mei 2012. Penelitian ini berbentuk penelitian korelasional, untuk melihat besaran hubungan antara kemampuan membaca dengan penguasaan konsep interaksi keruangan pada siswa SMA Negeri Kota Medan. Populasi penelitian adalah seluruh siswa kelas XI SMA Negeri di Kota Medan. Penetapan sekolah tempat dilaksanakan penelitian ditentukan berdasarkan peringkat sekolah menurut nilai akreditasi yang ditentukan secara proporsi. Berdasarkan akreditasi sekolah diperoleh bahwa ada 8 (delapan) sekolah dengan akreditasi A dan 13 ( tiga belas) sekolah dengan akreditasi B ( Dinas Pendidikan Kota Medan, 2012). Sesuai dengan data ini, maka jumlah sampel ditetapkan 3 (tiga) sekolah dengan akreditasi A dan 4 (empat) 
sekolah dengan akreditasi B yang dipilih secara random, sehingga jumlah sekolah tempat penelitian sebanyak 7 sekolah. Untuk penentuan siswa sebagai responden ditetapkan satu kelas dari masing-masing sekolah sampel yang diambil secara acak. Jumlah sampel diperoleh sebanyak 243 orang.

Untuk mengukur tingkatan penguasaan siswa dalam membaca peta digunakan 10 (sepuluh) indikator yaitu: penentuan judul, skala, simbol, warna, cara penulisan, orientasi, garis koordinat, legenda, insert, dan lay out peta, sedangkan untuk mengukur Penguasaan konsep interaksi keruangan dilihat dari 4 (empat) aspek, yaitu: adanya daya saling mempengaruhi antar wilayah, perbedaan pengembangan potensi, sumber, dan kebutuhan antar wilayah, perpindahan informasi, jasa, dan penduduk antar wilayah, dan kaitan fenomena/unsur dalam suatu wilayah. Penguasaan siswa diukur dengan menggunakan tes kemampuan dalam bentuk pilihan ganda. Sebelum tes ini digunakan untuk kepentingan penelitian, terlebih dahulu dilakukan ujicoba untuk melihat validitas dan reliabilitasnya. Untuk melihat validitas butir instrumen dilihat dengan menggunakan konistensi internal yaitu menghitung koefisien korelasi antara skor butir dengan skor totalnya dengan menggunakan rumus korelasi product moment, sedangkan untuk mengukur tingkat reliabilitasnya digunakan rumus KR-21. Hasil perhitungan menunjukkan bahwa instrumen kemamapuan membaca peta memiliki tingkat reliabilitas sebesar $\mathrm{r}=0,83$, sedangkan penguasaan konsep interaksi keruangan sebesar $\mathrm{r}=0,71$.

Dalam penelitian ini dikumpulkan 2 jenis data, yaitu : (1) data kemampuan membaca peta, dan (2) data penguasaan konsep interaksi keruangan. Kedua data ini dikumpulkan dengan menggunakan tes kemampuan, dan hasilnya diukur dalam bentuk skor. Teknik analisis data yang digunakan dalam penelitian ini adalah analisis statistik deskriptif dan statistik inferensial. Analisis statistik deskriptif dimaksud untuk memperoleh gambaran karakteristik gambaran nilai masing-masing variabel yang diteliti, dengan menghitung nilai rata-rata (mean), simpangan baku (SD), median (Me), modus (Mo) dan histogram.

Sebelum dilakukan pengujian hipotesis, terlebih dahulu dilakukan uji persyaratan yaitu uji normalitas, uji homogenitas dan uji linearitas regresi. Untuk uji normalitas digunakan $\chi 2$. kriteria pengambil keputusan adalah, gejala yang diamati dianggap berdistribusi normal jika $\chi 2$ hitung $<\chi 2$ tabel pada signifikansi 5\%. Untuk uji homogenitas varians dilakukan dengan uji Bartletts. Dengan kriteria pengambilan keputusan adalah gejala yang diamati dianggap homogen jika chi kuadrat hitung < chi kuadrat 
tabel pada taraf signifikan 5\% dengan derajat bebas sebanyak jumlah kelompok yang diharapkan dikurangi 1. Untuk uji lienaritas digunakan teknik analisis variansi (Sudjana, 1983) dengan kriteria pengambilan keputusan adalah terima model linear regresi jika harga $\mathrm{F}$ hitung < dari $\mathrm{F}$ tabel untuk taraf signifikansi 5\%. Pengujian keberartian harga $r$ dilakukan dengan menggunakan uji t. Kriteria yang digunakan adalah korelasi yang diperolah dikatakan signifikan jika harga t hitung > dari harga tabel untuk taraf signifikan 5\% dengan derajat kebebasan n-2, dengan demikian hipotesis yang diajukan diterima. Data dianalisis dengan menggunakan : (1) korelasi product moment dari pearson yang bertujuan untuk melihat besar hubungan antara variabel bebas dan varibabel terikatnya, (2) analisis regresi sederhana untuk mengetahui model hubungan antara variabel bebas terhadap variabel terikat. (Sudjana, 1983).

\section{Hasil Dan Pembahasan}

1. Hasil Penelitian

\section{a. Kemampuan Membaca Peta}

Kemampuan membaca peta pada penelitian ini diukur melalui 10 indikator. Hasil penelitian menunjukkan bahwa skor rata-rata capaian indikator diperoleh sebesar 49,98\%. Indikator yang skor pencapaiannya paling rendah adalah indikator skala peta yaitu sebesar 33,54 \%, dan yang skor rata-rata pencapaian indikator yang paling tinggi adalah indikator judul peta yaitu sebesar $81,46 \%$.

Berdasarkan data yang dikumpulkan dari hasil penelitian, untuk variabel kemampuan membaca peta mempunyai rentang skor antara 3 sampai 18. Nilai rata-rata (M) diperoleh sebesar 11,37, simpangan baku (SD), sebesar 2,85, median (Me) sebesar 11,35 dan modus (Mo) 11,33. Subjek penelitian yang memiliki skor di atas rata-rata sebanyak 58 orang $(23,87 \%)$, pada kelompok rata-rata sebanyak 89 orang $(33,63 \%)$ dan di bawah skor rata-rata sebanyak 96 orang $(39,51 \%)$.

\section{b. Penguasaan Konsep Interaksi Keruangan}

Untuk variabel penguasan konsep interaksi keruangan diukur melalui 4 aspek. Persentase skor capaian rata-rata untuk keempat aspek tersebut diperoleh sebesar 50,85\%. Aspek yang paling tinggi persentase skor capaian rata-ratanya adalah aspek kaitan fenomena/unsur dalam suatu wilayah sebesar 57,94 \%, sedangkan yang paling rendah skor capaiannya adalah aspek perbedaan pengembangan potensi, sumber, dan kebutuhan antar wilayah dengan skor capaian sebesar 45,69\%. 
Untuk variabel penguasaan konsep interaksi keruangan diperoleh rentang skor antara 3 sampai dengan 11 . Nilai rata-rata (M) sebesar 6,26 simpangan baku (SD) 2,01, median (Me) sebesar 6,17, dan modus (Mo) sebesar 5,48. Subjek penelitian yang memiliki skor di atas rata-rata 35 orang $(14,40 \%)$, pada kelompok rata-rata sebanyak 72 orang $(29,63 \%)$, skor di bawah rata-rata sebanyak 136 orang $(55,97 \%)$.

\section{c. Pengujian Hipotesis}

Hipotesis yang diajukan dalam penelitian ini adalah terdapat hubungan positif antara kemampuan membaca peta dengan penguasaan konsep interaksi keruangan. Model regresinya dinyatakan melalui persamaan $\hat{Y}=3,04+0,28$ X yang signifikan dan linear.

Untuk mengetahui hubungan antara variabel bebas (X) dan variabel terikat (Y) digunakan korelasi product moment. Hasil analisis menunjukkan koefisien korelasi antara kemampuan membaca peta dengan penguasaan konsep interaksi keruangan sebesar $r=0,402$ (tabel 6). Harga ini menunjukkan besarnya kekuatan hubungan antara kemampuan membaca peta dengan penguasaan konsep interaksi keruangan. Harga ini signifikan dan berarti karena hasil pengujian indek korelasi dengan uji $\mathrm{t}$ menunjukkan bahwa harga t hitung sebesar 6,816 lebih besar dari $\mathrm{t}$ tabel sebesar 1,65 dengan dk 241 pada $\alpha=0,05$. Hal ini berarti hipotesis nol (Ho) ditolak dan hipotesis yang diajukan dapat diterima. Artinya makin tinggi kemampuan siswa dalam mebaca peta maka makin tinggi juga penguasaannya tentang konsep interaksi keruangan. Koefisien korelasi yang diperoleh sebesar $\mathrm{r}=$ 0,402 berarti koefisien determinasinya sebesar $\left(\mathrm{r}^{2}\right)=0,1616$. Artinya bahwa kemampuan membaca peta memberi sumbangan sebesar $16,16 \%$ terhadap penguasaan konsep interaksi wilayah. Atau dengan kata lain variansi penguasaan konsep interaksi keruangan dapat dijelaskan oleh variansi kemampuan membaca peta sebesar $16,16 \%$.

\section{Pembahasan}

Persentase skor capaian rata-rata untuk variabel kemampuan membaca peta yang diukur dengan menggunaan 10 indikator diperoleh sebesar 49,98\%. Temuan penelitian menunujukkan bahwa dari 10 indikator yang digunakan, indikator yang memiliki skor pencapaian terendah ( paling sulit) adalah indikator skala dengan skor perolehan sebesar 33,54\%. Diduga hal ini disebabkan karena konsep perhitungan merubah skala peta sangat erat terkait dengan kemampuan perhitungan matematika. Jika dikaitkan dengan aspek kognitif seperti yang dikemukakan Bloom, maka butir soal penentuan skala peta tergolong pada 
tingkat aplikasi. Artinya untuk menyelesaikan soal pada tingkat ini, siswa harus memiliki penguasaan konsep skala yang benar ditambah dengan kemampuan perhitungan matematika. Untuk skor capaian indikator paling tinggi ( mudah), adalah indikator judul peta dengan skor perolehan sebesar 81,46\%. Artinya indikator ini merupakan indikator yang paling banyak dijawab benar oleh siswa. Hal ini diduga karena penentuan judul peta tidak membutuhkan taraf berfikir tinggi karena hanya menyangkut kemampuan ingatan saja.

Variabel penguasan konsep interaksi wilayah diukur dari 4 indikator Persentase skor capaian rata-rata untuk keempat indikator tersebut diperoleh sebesar 50,85\%. Dari keempat indikator yang digunakan, ternyata indikator yang paling tinggi persentase skor capaian rata-ratanya adalah aspek kaitan fenomena/unsur dalam suatu wilayah yang diperoleh sebesar 57,94 $\%$, sedangkan yang paling rendah skor capaiannya adalah indikator perbedaan pengembangan potensi, sumber, dan kebutuhan antar wilayah dengan skor capaian sebesar 45,69\%. Rendahnya pencapaian ini diduga karena untuk dapat memahami pengembangan potensi, sumber, dan kebutuhan antar wilayah maka siswa harus terlebih dahulu memahami berbagai aspek potensi yang terdapat di suatu wilayah. Secara keseluruhan tergambarkan bahwa skor capaian indikator kemampuan membaca peta, maupun variabel penguasaan konsep interaksi keruangan masih tergolong rendah.

Jika dilihat dari skor perolehan siswa maka tingkat penguasaan konsep region interaksi keruangan pada siswa SMA Negeri di kota Medan masih tergolong rendah. Ini terlihat dari hasil penelitian yang menunjukkan bahwa sebanyak 136 orang ( 55,97\%) dari 243 siswa berada pada kelompok skor di bawah rata-rata. Demikian juga halnya dengan kemapuan membaca peta masih tergolong rendah, karena hasil penelitian menunjukkan sebanyak 96 orang $(39,51 \%)$. dari jumlah sampel masih berada pada kelompok skor di bawah rata-rata.

Kondisi ini diduga bersumber dari belum optimalnya penggunaan peta sebagai media pengajaran geografi. Hal ini sejalan dengan pendapat Suharyono dan Amien (1994) yang menyatakan bahwa penggunaan aneka macam jenis peta dengan aneka macam pokok bahasan yang dipelajari akan dapat menunjang proses belajar mengajar serta tingkat penyerapan peserta didik dalam memahami konsep interaksi keruangan sebagai salah satu kajian geografi.

Selain itu rendahnya penguasaan konsep interaksi keruangan dan kemampuan membaca peta diduga tidak terlepas 
dari kurang optimalnya guru menggunakan peta yang sesuai dengan materi pokok kajian dalam proses pembelajaran geografi di kelas. Padahal peta berfungsi sebagai media pembelajaran utama dalam pembelajaran geografi. Daldjoeni (1982) menjelaskan bahwa peta diperlukan untuk membantu pemahaman siswa tentang hal-hal yang abstrak dan diluar jangkauan pengamatan langsung. Pendapat ini sejalan dengan pendapat Soemaatmadja (2001) yang menyatakan bahwa pembentukan citra dan konsep diri siswa untuk meningkatkan kognitif, afektif dan psikomotorik dalam mengajarkan geografi haruslah dengan memanfaatkan peta, karena tanpa penggunaan peta dalam belajar dan mempelajari geografi citra dan konsep yang baik pada diri siswa tidak akan terbentuk.

Hasil penelitian menunjukkan bahwa sumbangan yang diberikan oleh variabel kemampuan membaca peta dalam menjelaskan variansi variabel penguasaan konsep interaksi keruangan sebesar 16,16\% . Berarti, masih banyak variabelvariabel yang mempunyai hubungan dan mempengaruhi penguasaan siswa mengenai konsep ineraksi keruangan, seperti : ketersediaan peta sebagai media pengajaran di sekolah cara mengajar guru, motivasi siswa dan lain-lain yang tidak dilibatkan dalam penelitian ini. Memang sumbangan ini masih tergolong kecil namun demikian tetap harus dipertimbangkan dalam menjelaskan variansi penguasaan konsep interaksi keruangan.

\section{Kesimpulan Dan Saran}

\section{Kesimpulan}

Dari hasil penelitian yang telah diuraikan, maka dapat ditarik kesimpulan yaitu:

Kemampuan membaca peta pada penelitian ini diukur melalui 10 indikator. menunjukkan bahwa skor rata-rata capaian indikator masih tergolong rendah $(49,98 \%)$. Demikian juga untuk skor rata-rata capaian indikator penguasaan konsep interaksi keruangan masih tergolong rendah ( 50,85\%). Artinya lebih dari setengah soal yang ada dari tidak bisa dijawab dengan baik.

Hasil penelitian menunjukkan bahwa kemampuan membaca peta siswa SMA negeri kota Medan masih tergolong rendah karena 39,51\% masih di bawah rata-rata. Penguasaan konsep interaksi Keruangan juga masih rendah karena 55,97 \% masih di bawah rata-rata.

Hasil penelitian ini menunjukkan bahwa kemampuan membaca peta mempunyai hubungan positif dan berarti dengan penguasaan konsep interaksi keruangan. Bentuk hubungan tersebut ditunjukkan oleh persamaan regresi $\hat{Y}=3,04+0,28$ X. Koefisien 
korelasi antara variabel kemampuan membaca peta dengan variabel penguasaan konsep interaksi wilayah diperoleh sebesar $r$ $=0,402$. Harga ini signifikan karena pengujian keberartian korelasi menunjukkan bahwa harga t hitung $=6,816$ lebih besar dari harga $\mathrm{t}$ tabel pada $\alpha=0,05 \mathrm{dk} 241$ sebesar 1,65. Artinya bahwa semakin tinggi kemampuan membaca peta maka semakin tinggi pula penguasaan konsep interaksi wilayah. Temuan ini mendukung hipotesis penelitian bahwa terdapat hubungan positif dan berarti antara kemampuan membaca peta dengan penguasaan konsep interaksi keruangan.

Koefisien korelasi yang diperoleh sebesar 0,402 ( $\mathrm{r}^{2}=$ 0,1616), harga ini memberi arti bahwa kemampuan membaca peta memberi sumbangan sebesar $16,16 \%$ terhadap penguasaan konsep interaksi keruangan pada siswa SMAN kota Medan.

\section{Saran}

Berdasarkan temuan dari hasil penelitian yang dilakukan maka untuk meningkatkan kemampuan membaca peta dan penguasaan konsep interaki keruangan pada siswa SMAN Kota Medan maka:

a. Perlu terus meningkatkan penggunaan peta yang sesuai dengan pokok materi agar siswa memiliki peta mental dan konsep peta dalam dirinya yang secara praktis berguna pada saat membaca atau mendengar peristiwa yang terjadi dalam kehidupan seharihari

b. Mengintensifkan pertemuan MGMP untuk membicarakan permasalahan yang ditemukan di kelas, mensosialisasikan informasi-informasi penting yang diperoleh guru, karena berbagi dengan sesama bisa memberi jalan pemecahan pada permasalahan yang ada di kelas terutama dengan pembelajaran peta dalam kaitannya dengan penguasaan konsep interaksi keruangan

c. Menyediakan dan memambah sarana pembelajaran di sekolah khususnya peta sebagai media pembelajaran sehingga mudah diakses dan digunakan oleh guru dalam pembelajaran di kelas.

\section{Daftar Pustaka}

Berutu Nurmala \& Tumiar Sidauruk. 2002. Penguasaan Konsep Region Indonesia Ditinjau dari Kemampuan Membaca Peta (Suatu Studi pada Siswa SLTP Negeri di Kota Medan). Jurnal Pendidikan Volume 9 Edisi Khusus Nopember 2002 ISSN 0852 - 0151.

Hamalik, Omar. 1994. Media Pendidikan . Bandung : Alumni. Hermawan, Iwan. 2009. Geografi Suatu Pengantar. 
www.scribd.com/doc/60118975/25/A-Pengajaran-

Geografi-di-Indonesia. Diakses 25 Maret 2012 pukul 12.35 .

I.C.A, 1984. Basic Cartography, BAS Printer Limited Hampshire Jayadinata, Johara T. 1992. Tata guna tanah dalam perencanaan pedesaan perkotaan \& wilayah. Bandung : ITB

Kartawidjaja, Omi. 1988. Metoda mengajar geografi. Jakarta : Dirjen Dikti Depdikbud

Lubis,

FL .2012.

Repository.usu.ace.id/bitstream/123456789/31688/4/chapt er II.pdf

Nurcahyanto 88.wordpress.com/2011/04/05/pola-interaksi-desakota/. Diakses 25 Maret 2012, pukul 11.30 WIB

Prihandito, Aryono. 2001. Kartografi. Yogyakarta : Mitra Gama Widya

Sandy, I Made. 1976. Esensi kartografi. Jakarta : Direktorat Tata Guna Tanah

Siregar, M. R. 1993. Kartografi. Medan : IKIP Medan

Sjafrizal, 2008. Ekonomi Regional: Tiori dan Aplikasi. Padang : Praninta Offset

Sudjana, 1983. Teknik analisis regresi dan korelasi. Bandung: Tarsito

Suharyono \& Moch.Amin. 1994. Pengantar Filsafat Geografi. Jakarta: Dirjen Dikti Departemen Pendidikan dan Kebudayaan.

Sumaatmadja, Nursyid. 1988. Studi geografi suatu pendekatan dan analisa keruangan. Bandung: Alumni

2001. Metodologi Pengajaran Geografi.

Aksara. Jakarta.

Surapranata,Sumarna 2004. Analisis, Validitas, Reliabilitas dan Interpretasi Hasil Tes, Bandung: Rosda 